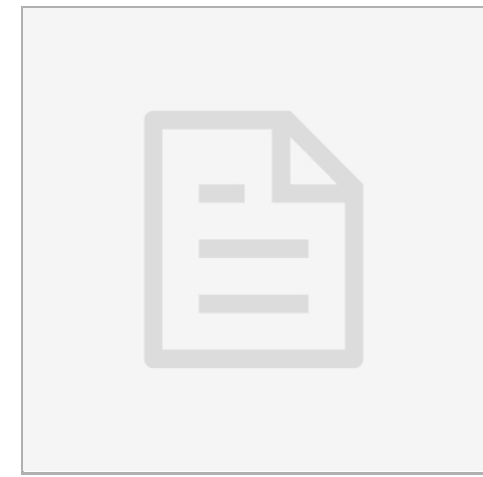

NOV 21, 2020

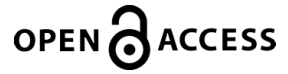

DOI:

dx.doi.org/10.17504/protocol s.io.bpximpke

Document Citation: Marco Cosentino, Elisa Storelli, Alessandra Luini, Massimiliano LM Legnaro, Emanuela Rasini, Marco Ferrari, Franca Marino 2020. SOLUTION- 02 - Phosphate Buffered Saline (PBS). protocols.io

https://dx.doi.org/10.17504/p rotocols.io.bpximpke

License: This is an open access document distributed under the terms of the Creative Commons Attribution License, which permits unrestricted use, distribution, and reproduction in any medium, provided the original author and source are credited

Created: Nov 21, 2020

Last Modified: Nov 21, 2020

DOCUMENT integer ID: 44746

Phosphate-buffered saline (PSB 1X)

$\mathrm{NaCl}-8 \mathrm{~g}(137 \mathrm{mM})$

KCl- $1.5 \mathrm{~g}(2 \mathrm{mM})$

\section{(3) SOLUTION- 02 - Phosphate Buffered Saline (PBS)}

\author{
Marco Cosentino ${ }^{1}, \quad$ Elisa Storelli ${ }^{1}$, Alessandra Luini $^{1}$, \\ Massimiliano LM \\ Emanuela Marco \\ Legnaro $^{1}$, \\ Rasini $^{1}$, \\ Ferrari $^{1}$, \\ Franca \\ Marino $^{1}$

\section{${ }^{1}$ Center for Research in Medical Pharmacology, University of Insubria (Varese)}

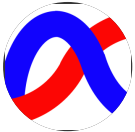

Farmacologia Medica

\section{ABSTRACT}

This recepe is used in the following protocols:

- Separation and purification of human PBMC from FRESH BLOOD

- Separation and purification of human PBMC from BUFFY COAT

- Magnetic bead-based CD4+ T cell isolation from PBMCs with Dynabeads: CD4

Positive Isolation Kit

- Magnetic bead-based TREG-TEFF cell isolation from PBMC with Miltenyi

CD4+CD25+ Regulatory T cell Isolation Kit

- Staining of human PBMC or ISOLATED SUBSETS with Cell Proliferation Dye-eFluor ${ }^{\mathrm{TM}}$ 670 (CPD-eFluor670) for cell proliferation evaluation by Flow Cytometry 
$\mathrm{Na}_{2} \mathrm{HPO}_{4}-1.44 \mathrm{~g}(10 \mathrm{mM})$

$\mathrm{KH}_{2} \mathrm{PO}_{4^{-}}-0.24 \mathrm{~g}(1.8 \mathrm{mM})$

To prepare $1 \mathrm{~L}$ of PBS $1 \mathrm{X}$, dissolve the reagents listed above in $800 \mathrm{~mL}$ of ultrapure $\mathrm{H}_{2} \mathrm{O}$. Adjust the $\mathrm{pH}$ to 7.4 with $\mathrm{HCl}$ or $\mathrm{NaOH}$, and then add $\mathrm{H}_{2} \mathrm{O}$ to $1 \mathrm{~L}$.

NaClcode: S9625, Sigma

KClcode: P9541, Sigma

$\mathrm{Na}_{2} \mathrm{HPO}_{4}$ code: 1.06585 , Sigma

$\mathbf{K H}_{\mathbf{2}} \mathbf{P O}_{\mathbf{4}}$ code: P0662, Sigma 